УДК 636.083.1

DOI: 10.37128/2520-6168-2021-4-15

Vol. 115, No 4 / 2021

\title{
USE OF DIGITALIZATION MEANS IN THE FORMATION OF THE MICROCLIMATE OF ANIMAL PREMISES
}

Olena Trukhanska, Ph.D., Associate Professor

Vinnytsia National Agrarian University

Труханська Олена Олександрівна, к.т.н., доцент

Вінницький національний агарний університет

The study of information systems and technologies, specialized software products aimed at solving the problems of animal husbandry management and determining the prospects for their use by specialists is relevant.

The main factor determining the life of animals is the environment. One of the ways to intensify livestock (pigs, cattle, poultry, etc.) is a comprehensive automation of labor-intensive technological processes, including the formation of the microclimate of livestock facilities, which would have a positive impact on animal health, productivity and product quality. However, animals are also affected by certain methods and methods of feeding, man-made content, zonal climate, heat-shielding properties of enclosing structures, air exchange rate, ventilation efficiency, sewage condition, manure removal and removal methods, lighting.

The impact of microclimate on animals consists of a set of environmental factors: temperature, humidity, air velocity, chemical composition, microbial and dust pollution, lighting, etc. The main parameter of the air environment is temperature. This has the greatest impact on animal health and productivity. The hygienic value of temperature is that it affects the thermoregulation of the body, which is divided into the processes of chemical thermoregulation - the reaction of heat generation and the processes of physical thermoregulation - the regulation of heat transfer.

The study of the technology of improving the efficiency of microclimate regulation in livestock premises based on the use of an automated control system is promising.

Thus, changing the composition and properties of the environment, you can affect the body of animals, achieving high productivity.

Key words: animals, vital activity, microclimate, premises, temperature, humidity, means of digitalization.

Table. 1. Fig. 2. Ref. 9.

\section{Introduction}

Air temperature is the main physical stimulus of animals. The hygienic value of ambient temperature is that it has a great influence on the thermoregulation of animals. Depending on the ambient temperature, the body adapts or rebuilds its thermoregulation. When the temperature decreases as a result of increased metabolism in the body, heat production increases and heat transfer decreases, and when the air temperature rises to certain limits - heat production and heat transfer increases [1].

\section{Problem formulation}

Disturbances in heat transfer can be caused not only by high and low ambient temperatures and objects, of great importance is high humidity and air velocity. Young animals are especially sensitive to low temperatures [2].

Deterioration of the microclimate reduces the service life of livestock facilities and their technological equipment.

In addition to species and age characteristics and density of animals on the microclimate in the livestock room are also influenced by factors:

- climatic conditions;

-constructive features of the building and materials from which its elements are made;

- methods of keeping animals; feed distribution; manure cleaning, etc.

One of the ways to intensify production and commercial activities is to raise awareness of market conditions, scientific achievements and innovations, all processes in enterprises and, as a consequence, the quality and efficiency of management decisions. This is possible with the introduction and use of information systems and technologies.

\section{Analysis of recent research and publications}

Many scientists have studied the transfer of innovations in animal husbandry through information and consulting services [1-3]. 
Livestock air contains significant amounts of harmful gases such as carbon dioxide, hydrogen sulfide, ammonia and products of decomposition and fermentation of organic matter. The gas composition of indoor air is largely determined by their sanitary condition, the density of animals, methods of cleaning and removing manure, the level of air exchange, etc. [4].

The success of animal husbandry is determined by $60 \%$ feeding, $20 \%$ breeding and age and $20 \%$ microclimate and housing conditions. Since the microclimate of the livestock space is a set of physical and chemical parameters of its environment, the deviation of these parameters from physiologically determined norms weakens the resistance of animals to disease, causes a fall of young (especially poultry) to $40 \%$, reduced milk yield by $10 \ldots 20 \%$, reduced weight gain for fattening up to $30 \%$ and requires additional feed costs.

The air regime is disturbed during the respiration of animals (release of heat, moisture, carbon dioxide, etc.), as well as as a result of manure evaporation. With increasing humidity in the premises of the evaporation of moisture by the respiratory organs of animals decreases, as the partial pressure of water vapor approaches the elasticity of water vapor on the surface of the mucous membranes of the respiratory tract.

In addition, moisture, saturating the air in the room, changes their heat capacity and thermal conductivity. High relative humidity ( $85 \%$ and above) has a negative effect on heat transfer, both at high and low ambient temperatures. Harmful to animals not only very humid but also very dry air (relative humidity below 40\%). The movement of air at a temperature lower than the body temperature of the animal can cause hypothermia. In animal housing, air velocity is an important factor in heat transfer. It, increasing evaporation and increasing heat transfer, affects the water and heat exchange of animals. Significant impact on the body of animals in addition to temperature, humidity and air velocity has a gaseous composition of ambient air [5, 6].

The proliferation and availability of mobile devices and wireless networks has led to the emergence of a large number of mobile applications. The initiators of the development may be suppliers of inventory and services for enterprises in the industry or software developers. In the first case, applications are often provided free of charge, but contain advertising elements, in the second - the installation and use of the program requires payment. In particular, for livestock in Google Play offers dozens of applications, mostly of foreign origin [7-9].

Currently, among the promising free are:

«Poultry Helper - Incubator and Brooder» is focused on households and farms, designed to administer the regimes of keeping, feeding and breeding birds.

Control Ganadero is an application for managing dairy farms through individual monitoring of animals equipped with QR-code tags. It is determined that this is relevant for animals in the pasture form of keeping. Functionality also allows you to control the production and sales of products. «Digitanimal» - for GPS control of the location and condition of the animal. Gestion porcine - to control the breeding of pigs. Additionally, the following communication applications are used - messengers (Viber, Messenger, Telegram, WhatsApp) and video conferencing systems (Skype, Zoom, Google Meet).

There are several promising areas of information systems and technologies in animal husbandry: information support, the use of information systems and technologies in the management of production processes, accounting, procurement and marketing, optimization of resource use, decision support.

\section{A purpose of work}

The aim is to study information systems and technologies, specialized software products aimed at solving the problems of animal husbandry management and determine the prospects for their use.

\section{Results of research}

Among the main factors of pollution that most affect the development of animals are gases (carbon monoxide, ammonia, hydrogen sulfide), moisture and heat (Table 1) [10].

Table 1.

Maximum permissible concentrations of harmful gases in the air of livestock and poultry premises

\begin{tabular}{|c|c|c|}
\hline \multirow{2}{*}{ Harmful gas } & \multicolumn{2}{|c|}{ Premises } \\
\cline { 2 - 3 } & Animal & Poultry house \\
\hline Carbon dioxide, $1 / \mathrm{m} 3$ & 2,5 & 2,0 \\
\hline Ammonia, $\mathrm{mg} / \mathrm{l}$ & 0,02 & 0,01 \\
\hline Hydrogen sulfide, $\mathrm{mg} / \mathrm{l}$ & 0,01 & 0,005 \\
\hline
\end{tabular}

Thus, at air temperatures below a certain limit, part of the feed is spent on maintaining the level of heat in the body. At too high temperature of air at animals appetite decreases. High humidity leads to colds in animals. The health and productivity of animals is affected by the chemical composition of indoor air. Ammonia, hydrogen sulfide, carbon dioxide reduce the body's resistance to disease.

If the farm does not worry about the ventilation of livestock facilities, creating an optimal microclimate, it loses tens of tons of milk and meat annually and receives low quality products. 


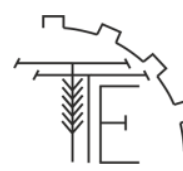

Therefore, it is important to maintain the stability of the level of microclimate indicators.

In contrast to the technical provision of ventilation and space heating in livestock complexes of the past, in the projects of modern enterprises the optimal microclimate is provided locally, in accordance with the physiological requirements of animals directly in the area of their location.

The study of the technology of improving the efficiency of microclimate control in the livestock space based on the use of automated control system SCADA (Supervisory Control and Data Acquisition) is promising. This will allow to more correctly maintain the parameters of the microclimate in the livestock room by adjusting the results for the sensors of the system of internal and external parameters and entering these results into the program of microclimate management in the livestock room (Fig. 1) [10].
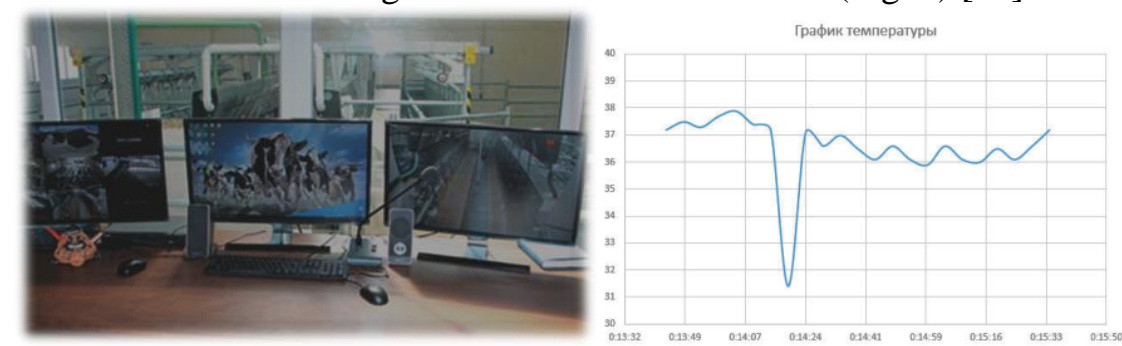

Fig.1 Automated control system SCADA (Supervisory Control and Data Acquisition)

At the moment it is not possible to completely replace human labor with machine work. No matter how smart the production, they still require supervision and control.

So. when developing an automated control system (ACS) use two levels of control (Fig. 2).

Lower level of ACS:

Continuous regulation of technological parameters (temperature, pressure, etc.) and software and logic control of various mechanisms (valves, valves, motors, conveyors, etc.). Today the base level is programmable logic controllers (Programmable Logical controller)

Top level:

Supervisory level (SCADA), supervisory control and data collection - HMI (Human-machine interface), human-machine interface or HMI / SCADA.

Supervisory management is to identify the situation on the site and assign tasks to the lower level.

HMI / SCADA - industrial software that implements data exchange with the controller, as well as interaction between the decision maker and directly to the control system.

The SCADA system must provide the following functions:

- HMI (Human-machine interface) -visualization of the control object and all current parameters (system status, process, status of individual units, devices);

- Collection and archiving of all data coming from controllers (SCADA-system allows you to see how the parameters of the technological process change in real time, as well as view information for a certain period in the past.);

- Display of data and notification of events in the system (for example, on the graph we can see that exactly at 14:18 some parameter falls sharply or increases by a certain amount);

- Logging of events (Operator is obliged to respond to emergencies according to the instructions, which can also be immediately provided by the SCADA-system. All events are archived by the system and if necessary can be viewed and used during analysis);

- Differentiation of user rights (SCADA system provides for its use by several users with different rights.);

- Implementation of the reporting system (allows you to choose only the most necessary information and draw on it the correct conclusions about the work of production, which in turn leads to optimization and improvement of efficiency).

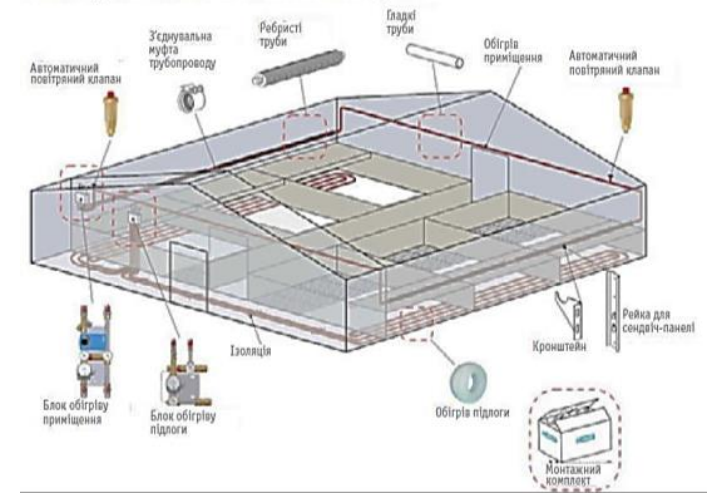

Fig.2. Example of application of automated control system (SCADA) 


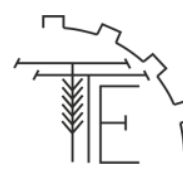

Vol. 115, No 4 / 2021

Livestock farms and complexes (cattle, pig farms) in Ukraine use two traditional heating systems: floor heating and space heating. Regardless of the type of space heating system, three basic principles should be followed:

- heating must be uniform;

- uniform distribution of heating pipes;

- control panel control and ventilation system control.

Therefore, a SCADA system is needed to save material resources and increase efficiency. This is achieved through:

1. Reduce the cost of repairs and simple equipment due to quick response and accident prevention.

2. Effective production analysis and optimization based on the information obtained.

3. Improving the quality of staff work through strict control and user-friendly interface. production.

4. Total and continuous control over all processes. Vision of a holistic and reliable picture of

5. Ability to make faster decisions on production management in response to emerging issues.

\section{Conclusions}

Resource management of any element of the system can be built on the principles of optimization, individual approach, reasonableness and predictability. In production and supply chains it will be possible to provide full traceability and coordination, to create optimal models of management of livestock farms and complexes. Effective animal husbandry in modern conditions involves the economical use of resources, balanced production, taking into account a large number of production and market factors, environmental friendliness of the industry.

Global trends in digitalization involve the widespread introduction of information systems and technologies in the management of information flows and production processes.

Digital agriculture will create systems that will be characterized by high productivity, predictability and the ability to adapt to change. This, in turn, can help increase food security, profitability and sustainability.

\section{References}

[1] Aliev, E.B., Yaropud, V.M., Bilous, I.M. (2020). Obgruntuvannia skladu enerhozberihaiuchoi systemy zabezpechennia mikroklimatu v svynarskykh prymishchenniakh. Vibratsii v tekhnitsi ta tekhnolohiiakh. 2(97). 127-137. [in Ukrainian].

[2] Moroz, S.I. (2020). Vykorystannia informatsiinykh system i tekhnolohii v upravlinni tvarynnytstvom. Elektronne naukove fakhove vydannia «Efektyvna ekonomika», 5. 4 p. URL : http://www.economy.nayka. com.ua/pdf/5_2020/81.pdf [in Ukrainian].

[3] DSTU 7823:2015 Fermy tvarynnytski. Vymohy do parametriv mikroklimatu tvarynnytskykh prymishchen. Pryiniato ta nadano chynnosti: nakaz DP «UkrNDNTs» vid 22 chervnia 2015 r. 61 z 201604-01. [in Ukrainian].

[4] Stadnik, M.I., Hrytsun, A.V., Protsenko, D. P. (2019). Metod pokryttia hrafiku navantazhennia tvarynnytskoi fermy pry avtonomnomu elektropostachanni, na bazi biohazovykh ustanovok. Tekhnika, enerhetyka, transport APK. 4(107). 79-87. [in Ukrainian].

[5] Aliev, E., Bandura, V., Pryshliak, V., Yaropud, V., Trukhanska, O. (2018). Modeling of mechanical and technological processes of the agricultural industry. INMATEH - Agricultural Engineering. 54 (1). 95104. [in English].

[6] Prohramma dlia effektyvnoho upravlenyia molochnoi fermoi DairyComp 305. Sait Soft-Ahro. URL : https://soft-agro.com/dairycomp-305. [in Ukrainian].

[7] For Dairy Cow Farmers. UNIFORM-Agri. URL : https://www.uniform-agri.com/gl/products/dairycow-farmers. [in Ukrainian].

[8] Prohrammy dlia selskoho khoziaistva. URL : https://www.korall-agro.ru/ [in Ukrainian].

[9] SCADA systemy. URL : https://myscada.com.ua/ua/blog/chto-takoe-scada. [in Ukrainian].

\section{ВИКОРИСТАННЯ ЗАСОБІВ ЦИФРОВІЗАЦЇ̈ ПРИ ФОРМУВАННІ МІКРОКЛІМАТУ ТВАРИННИЦЬКИХ ПРИМЩЕНЬ}

Дослідження інформаційних систем $і$ технологій, спеціалізованих програмних продуктів, спрямованих на розв'язання завдань управління тваринництвом та визначення перспектив їх використання фахівцями є актуальним.

Основним чинником, щуо визначає життєдіяльність тварин є навколишнє середовище. Одним із иляхів інтенсифікації тваринництва (свинарства, ВРХ, птахівництва та інш.) є комплексна автоматизація трудомістких технологічних процесів, в тому числі і у формуванні мікроклімату 


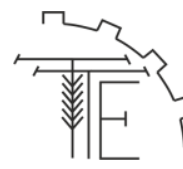

тваринницьких приміщень, який би сприятливо впливав на стан здоров'я тварин, їх продуктивність та якість продукиї. Проте, на тварин впливають також певні прийоми і способи годівлі, утримання, итучно створювані людиною, зональний клімат, теплозахисні властивості огороджуючих конструкиій приміщень, рівень повітрообміну, ефективність вентиляції, стану каналізації, способів прибирання та видалення гною, освітленість.

Вплив мікроклімату на тварин складається з комплексу факторів зовнішнього середовища: температури, вологості, швидкості руху повітря, хімічного складу, мікробної і пилової забрудненості повітря, освітленості та інщ.. Основним параметром повітряного середовища приміщення $\epsilon$ температура. Вона найбільшою мірою впливає на стан здоров'я і продуктивність тварин. Гігієнічне значення температури в тому, щуо вона робить вплив на терморегуляцію організму, щзо підрозділяється на процеси хімічної терморегулящії - реакиії теплопродукції $i$ процеси фізичної терморегуляиї - прочеси регуляиї тепловіддачі.

Перспективним є дослідження технологї підвищення ефективності регулювання параметрів мікроклімату у тваринницькому приміщенні на основі застосування автоматизованої системи керування. Таким чином, зміною складу та властивостей навколишнього середовища можна впливати на організм тварин, досягаючи високої продуктивності.

Ключові слова: тварини, життєдіяльність, мікроклімат, приміщення, температура, вологість, засоби цчифровізації.

Табл. 1. Рис. 2. Ліm. 9.

\section{ИСПОЛЬЗОВАНИЕ СРЕДСТВ ЦИФРОВИЗАЦИИ ПРИ ФОРМИРОВАНИИ МИКРОКЛИМАТА ЖИВОТНОВОДЧЕСКИХ ПОМЕЩЕНИЙ}

Исследование информационных систем и технологий, специализированных программных продуктов, направленных на решение задач управления животноводством и определение перспектив их использования специалистами актуально.

Основным фактором, определяюшим жизнедеятельность животных, является окружающая среда. Одним из путей интенсификации животноводства (свиноводства, КРС, птицеводства и др.) является комплексная автоматизация трудоемких технологических прочессов, в том числе и в формировании микроклимата животноводческих помещзений, благоприятно влияющих на состояние здоровья животных, их продуктивность и качество продукции. Однако на животных влияют также определенные приемы и способы кормления, содержания, искусственно создаваемые человеком, зональный климат, теплозащчитные свойства ограждающих конструкций помещений, уровень воздухообмена, эффективность вентиляции, состояния канализацчи, способов уборки и удаления навоза, освешенность.

Воздействие микроклимата на животных состоит из колплекса факторов внешней средь: температуры, влажности, скорости движения воздуха, химического состава, микробной и пьлевой загрязненности воздуха, освещченности и т.д. Основным параметром воздушной среды помещения является температура. Она в большей степени влияет на состояние здоровья и продуктивность животных. Гигиеническое значение температуры в том, что она оказывает влияние на терморегуляцию организма, разделяемого на процессы химической терморегуляции - реакции теплопродукичи и процессы физической терморегуляичи - процессы регулячии теплоотдачи.

Перспективно исследование технологии повышения эффективности регулирования параметров микроклимата в животноводческом помещении на основе применения автоматизированной системы управления. Таким образом, изменением состава и свойств окружающей средь можно воздействовать на организм животных, достигая высокой продуктивности.

Ключевые слова: животные, жизнедеятельность, микроклимат, помещение, температура, влажность, средства ичифровизации .

Табл. 1. Рис. 2. Лит. 9.

\section{INFORMATION ABOUT THE AUTHORS}

Olena Trukhanska - Ph.D, Associate Professor, Vinnytsia National Agrarian University (Sonyachna St.3, Vinnytsia, 21008, Ukraine e-mail: seaswallow@ukr.net, https://orcid.org/0000-0001-8481-8878).

Труханська Олена Олександрівна - к.т.н., доцент Вінницький національний аграрний університет (вул. Сонячна, 3, м Вінниця, 21008, Україна, e-mail: seaswallow@ukr.net, https://orcid.org/0000-0001-8481-8878 ).

Труханская Елена Александровна - к.т.н., доцент Винницкий национальный аграрный университет (ул. Солнечная, 3, г. Винница, 21008, Украина, e-mail: seaswallow@ukr.net, https://orcid.org/0000-0001-8481-8878). 